\title{
Following the Yellow Brick Road: Yellow slip clays and the production of Rio Grande Glaze Ware in north central New Mexico
}

Suzanne L. Eckert*a, Kari L. Schleher ${ }^{\mathrm{b}}$, and David H. Snow ${ }^{\mathrm{c}}$

"corresponding author: phone (520) 626-0253; fax (520) 621-2976; e-mail

sleckert@email.arizona.edu

aArizona State Museum, University of Arizona, PO Box 210026, Tucson, AZ 85721-

0026

bCrow Canyon Archaeological Center, 23390 Road K, Cortez, CO 81321

'Independent Scholar, 1616 Prospect Ave NW, Albuquerque, NM 87104

\section{Abstract}

This provenance study of yellow-firing clays in north central New Mexico examines whether clays recovered in the vicinity of Tunque Pueblo (LA 240) may have been used as slip clays at contemporaneous San Marcos Pueblo (LA 98). A sample of 72 ceramic sherds, bricks, and clays were analyzed through chemical characterization using laser-ablation inductively coupled plasma mass spectrometry (LA-ICP-MS). We argue that Tunque potters were using a subset of clays available at their village to produce pottery. Although San Marcos potters appear to have possibly been using clay from Tunque Pueblo to slip their vessels, these clays were not the same as those used by Tunque potters. Given San Marcos potters' apparent reliance on this slip clay over time, we argue our findings demonstrate that extremely stable social networks were developed and sustained among Rio Grande Pueblo households and communities across north central New Mexico during the late prehispanic and early colonial periods (AD 1400-1680).

keywords: LA-ICP-MS; pottery; ceramic slips; American Southwest; Rio 
Grande Pueblos; provenance

\section{Introduction}

Among ethnohistoric potters, the raw materials used to make pottery often come from a variety of locations. Some resources such as clay or temper are widely available and are typically obtained close to the area of production (Arnold 1985). Other resources, such as slip clays or pigments, are more limited in their availability and potters may travel longer distances to obtain these materials (Dillingham 1992; Najohai and Phelps 1998; Parsons 1932). Acquisition of these more specialized materials are embedded within social and economic networks of varying scales; this may have also been the case in the past (Herhahn 2006; Huntley et al. 2012; Nelson and Habicht-Mauche 2006). In this study, we are specifically examining the provenance of yellow-firing clays used in the production of Ancestral Pueblo glazepainted pottery at two villages in north central New Mexico.

The majority of ceramic provenance studies in the Southwest United States have focused either on mineralogical analyses (Capone 2006; Eckert 2008; HabichtMauche 1993, 2002; Shepard 1942) or bulk chemical compositional techniques (Crown 1994; Glowacki et al. 1998; Huntley 2008). However, the development of numerous chemical compositional techniques has provided multiple avenues for archaeologists to explore the provenance of specific clays, tempers, slips, and paints (e.g., Duwe and Neff 2007; Habicht-Mauche et al. 2000). This research focuses on understanding the provenance of the yellow-firing clay used as slip on glazedecorated pottery produced during the 14th through 17 th centuries in north central New Mexico (Figure 1). Specifically, we collected chemical signatures derived from laser ablation-inductively coupled plasma-mass spectrometry (LA-ICP-MS) of historic 
Figure 1: Map of north central New Mexico, showing location of Tunque and San Marcos Pueblos, as well as other large, contemporaneous villages in the Galisteo Basin (map by Grant Coffey).

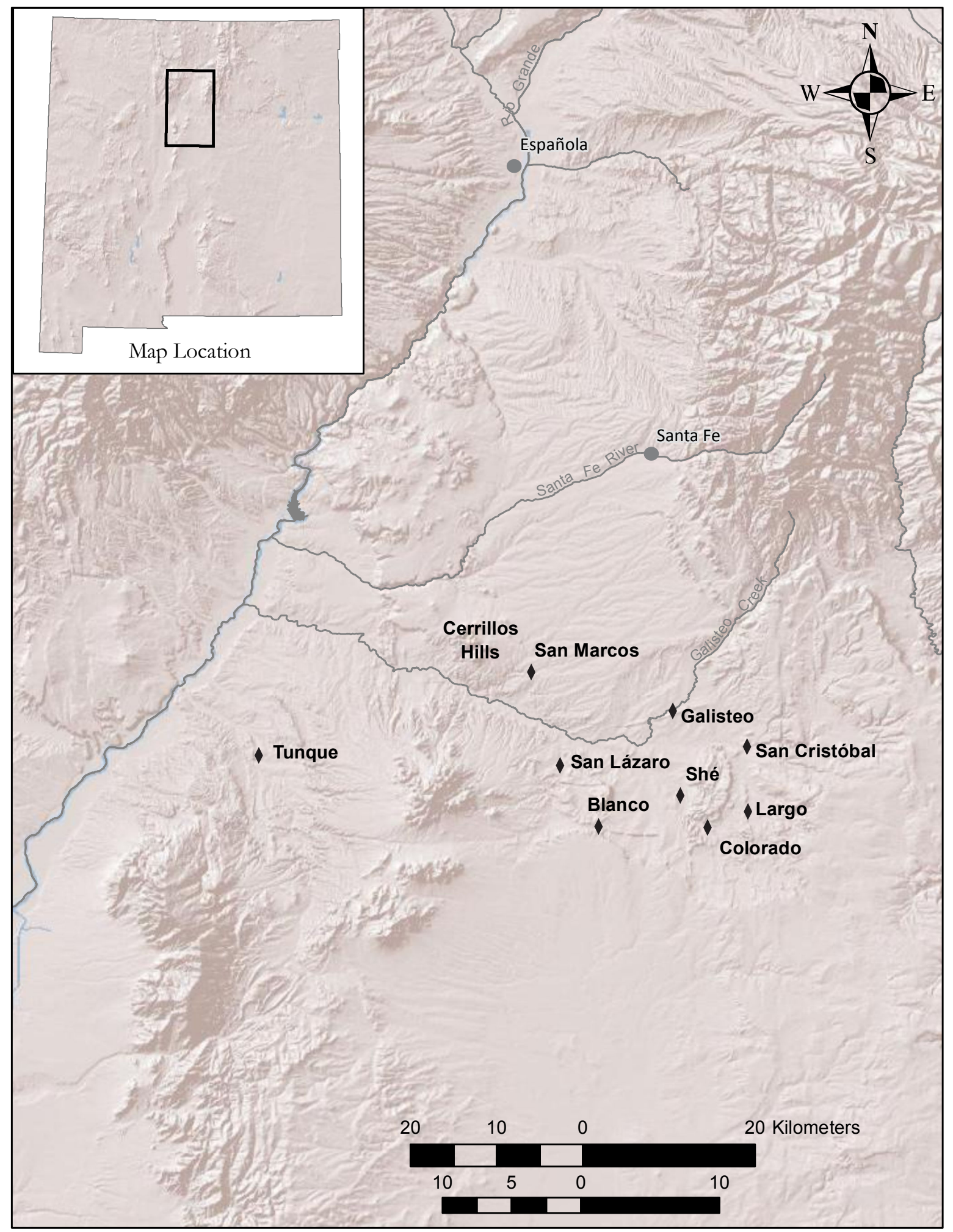


bricks, clay samples, and ceramic sherds from Tunque Pueblo (LA 240) and San Marcos Pueblo (LA 98). We interpret these data to explore the distribution of raw materials required to make pottery and to discuss social networks that may have facilitated the movement of these materials.

Our goals were threefold. First, we wanted to identify which of the clays available in the vicinity of Tunque Pueblo were used by late prehispanic and early colonial (AD 1400-1680) potters to produce yellow-slipped glaze-painted pottery. Not surprisingly, we found that Tunque Pueblo potters were using a selection of the yellow-firing clays available near their village. Second, we wanted to explore whether or not the clays available at Tunque Pueblo were used by potters at San Marcos Pueblo, located about $30 \mathrm{~km}$ to the northeast. We argue that San Marcos potters were probably using yellow-firing clays from Tunque Pueblo to slip at least some of their vessels, however these slip clays were not the same as those used by Tunque potters for the body of their vessels. Third, we explore what these data tell us about the nature of social networks among villages during the late prehispanic and early colonial periods in north central New Mexico. We argue that it is more appropriate in the context of our study to discuss how strategies of resource acquisition built enduring social relationships between specific households and villages within this region rather than to discuss 'local' versus 'nonlocal' pottery production per se.

\section{The Archaeological Setting}

Early in the fourteenth century, major demographic shifts occurred in north central New Mexico including a significant population increase (Snead et al. 2004). Villages built at this time were much larger than previously dispersed settlements (Crown et al. 1996). The rapid construction of so many large villages has led 
researchers to suggest various models of social reorganization including tribalization (Habicht-Mauche 1993), clustered confederacies (Spielmann 1994), and alliances (Creamer 2000; Creamer and Haas 1998; Wilcox 1991). Archaeologists have recognized changes in other social dynamics that are associated with these settlement shifts, including new ritual systems, expansion of exchange networks, and dramatic changes in ceramic production traditions (Eckert 2008; HabichtMauche 1993; Habicht-Mauche et al. 2006; Huntley 2008; Spielmann 1998).

In conjunction with these demographic changes, most potters moved away from making black-on-white pottery and began to produce glaze-decorated pottery known as Rio Grande Glaze Ware (Eckert 2006). Slip color is often the defining characteristic that distinguishes among varieties and types of Rio Grande Glaze Ware vessels (Eckert 2006). Yellow as a slip color was first identified by Nelson in his study of Tano ruins (Nelson 1916). Since then the term 'yellow' has been used in the formal descriptions of various Rio Grande Glaze Ware types (Eckert 2006; Kidder and Kidder 1917; Kidder and Shepard 1936; Nelson 1916). However, the descriptor 'yellow' often refers to a broad range of light surface colors that can vary markedly even on the same vessel. Kidder and Kidder (1917) noted that the slips were "yellowish" or "pinkish-gray," and "white through cream to yellow." Mera (1933: 4) observed that, "although termed yellow," it might even be a dirty white. Kidder and Shepard (1936: 80) remarked that Pecos Glaze II slips "can only be described as light," as the color variety is "endless, and is never really white or truly yellow or positively gray, but ranges from dirty yellowish, or grayish, to pinkish buff." As such, the generic descriptive term 'yellow' has been used in the archaeological literature more to emphasize the break in technology from the preceding black-on-white 
ceramic series, as well as in comparison with the contemporaneous red series of Rio Grande Glaze Ware types, than to denote a specific color.

In an attempt to increase our understanding of the production and distribution of yellow-slipped pottery, we focus this study on vessels recovered from two villages that were major centers of glaze-painted pottery manufacture: Tunque Pueblo and San Marcos Pueblo. Tunque Pueblo seems to have been at the height of its population from AD 1450 to 1550 (Armstrong et al. 2011). Both Nelson's early excavations and more recent fieldwork (Armstrong et al. 2011; Barnett 1969; Bice 1990; Morales 1997) recovered direct evidence for pottery manufacture at Tunque Pueblo including puki fragments (molds used for starting hand built vessels), potpolishing stones, fired and unfired clay, and various slip clays and pigments. Pottery manufactured at Tunque Pueblo can be identified by the presence of a particular type of temper: hornblende latite ash (Habicht-Mauche 1993; Nelson and HabichtMauche 2006; Warren 1969, 1979, 1981).

San Marcos Pueblo's chronology is complex (Ramenofsky et al. 2009; Ramenofsky and Schleher 2017), but the site appears to have been occupied throughout the entire Rio Grande Glaze Ware sequence (A.D. 1300 - 1680). Pottery manufactured at San Marcos Pueblo can be identified by the presence of a particular type of temper: weathered augite monzonite (Habicht-Mauche 1993; Nelson and Habicht-Mauche 2006; Schleher 2010; Warren 1979, 1981). Schleher (2010: 111) has convincingly demonstrated that, depending on time period, an average of $81 \%$ of the total sample of glaze-painted pottery recovered at the pueblo was produced at this village based upon petrographic analyses.

Of specific interest to us is that, although yellow-slipped pottery was produced 
at both villages, yellow-firing clays are more readily available at Tunque Pueblo than at San Marcos Pueblo. Specifically, Snow has noted in various informal settings the yellowish hue of some of the bricks produced at the historic Tonque Brick Works factory on the west edge of the ruins. He has suggested that Tunque potters not only used this easily available clay in the production of their own yellow-bodied (unslipped and polished) pottery, but might have provided the yellow slips for similar (albeit red-bodied) pottery produced at other villages during the same period, especially San Marcos Pueblo. The clay deposits closest to San Marcos pueblo fire red (Schleher 2010; Schleher et al. 2002); yet, large amounts of yellow-slipped pottery were produced at San Marcos for close to four centuries (Schleher 2010; Ramenofsky 2012).

Based on prolific amounts of glaze ware pottery exported from these two sites, San Marcos and Tunque Pueblos were arguably the largest producers of glaze-onyellow pottery from the 1400s through the 1500s (Warren 1969, 1979); but they were not the only producers of Rio Grande Glaze Ware in the region (Creamer 2000; Nelson and Habicht-Mauche 2006; Reed 1990). Other villages in the nearby Galisteo Basin exhibit evidence of pottery production, including San Lazaro (Blinman et al. 2012; Fenn 2004; Warren 1979), San Cristobal Pueblo (Reed 1990; Warren 1979), and Pueblo Galisteo (Warren 1979). As a matter of fact, both Reed (1990) and Warren (1979) suggested that almost every site they examined in the Galisteo Basin produced at least some pottery, an observation that requires more extensive research than offered here.

Because San Marcos and Tunque Pueblos have been the focus of more extensive research on pottery production than other Galisteo Basin villages, the 
unique temper signatures that exist for these two pueblos have yet to be determined for the other villages. The presence of various types of igneous rock temper is used to identify pottery production at Galisteo Basin sites other than San Marcos Pueblo (Habicht-Mauche 1993; Nelson and Habicht-Mauche 2006; Warren 1979, 1981). Based on the current evidence, none of the potters at these other Galisteo Basin villages were as major producers as the potters at San Marcos and Tunque Pueblos. With this in mind, and with our limited resources to do chemical characterization sampling, it made sense to focus this project on these two villages. If residents of Tunque Pueblo could have supplied villages such as San Marcos Pueblo in the north-central Rio Grande villages with slip clay, then this knowledge has important implications for modeling regional social networks and economic interaction during the late prehispanic and early colonial periods. Such modeling can help inform, but also be refined by, further research at other villages throughout the Galisteo Basin.

\section{The Geological Setting}

Geologically, the Galisteo-Tonque area lies on the eastern edge of the Rio Grande Depression, and extends from the north end of the Sandia Mountains to the south end of the Sagre de Cristo Mountains (Stearns 1953). The geology in this area of north-central New Mexico is highly variable (Scholle 2003), having been formed by fluvial deposition, alluvial redeposition, surface volcanism, intrusive igneous activity and associated deformation, and periods of erosion. This geological diversity is ideal for archaeological studies, allowing for potential characterization of temper, clay, and pigment across the landscape. The current study focuses on clay available within an approximately 5-kilometer radius of two sites as an initial attempt to trace the movement of slip clay; but the geology of the greater region will need to be 
considered in future studies that attempt to more clearly reconstruct past social interactions.

Tunque Pueblo sits atop the Mancos Group (Scholle 2003), which is dominated by shale and other mudrocks (Stearns 1953). Within an easy walk from the site lies the Mesa Verde Formation (which overlies the Mancos Group), dominated by sandstones and shales. Unique to this area is the Cano Member of the Mesa Verde Formation, a tongue of sandstone interbedded within the underlying Mancos Group and only recognized in the Tonque Valley (Stearns 1953). Also within $5 \mathrm{~km}$ is the Todilto Limestone of the Wanakah Formation, overlain by massive gypsum. The Galisteo Formation (1/3 of which consists of deep-red, maroon, and purple clays) and the Dockum Group (composed of red and variegated sandstone and shale) also lie within approximately $5 \mathrm{~km}$ of the site (Stearns 1943, 1953).

With the exception of the Todilto Limestone, the geological setting of Tunque Pueblo provides various red (high-iron) and yellow (low-iron) firing clays suitable for pottery production. Local clays used to produce bricks at the Tonque Brick Works fired to light red, reddish yellow, and very pale brown (considered yellow for our purposes here) based on Munsell soil chart (only the yellow bricks were used in this study). Clay samples collected from on or near Tunque Pueblo and fired by the authors produced the same range of yellow and red hues as the bricks (only the yellow samples were used in this study). The unslipped surface of glaze-on-yellow pottery produced at Tunque Pueblo exhibit a slightly greater range of hues than the brick and clay samples, but include the same light red, reddish yellow, and very pale brown.

San Marcos Pueblo sits atop the Espinaso Volcanics (Scholle 2003), comprised 
primarily of latite but also andesite and other intermediate volcanic material; intermediate igneous intrusions unassociated with these volcanics are also within 5 $\mathrm{km}$ of the site (Stearns 1953). As with Tunque Pueblo, San Marcos Pueblo is within $5 \mathrm{~km}$ of the Mancos Group (specifically the Dakota Sandstone Subdivision) and the Mesa Verde Formation. A poorly defined pediment - alternatively referred to as mesa gravels (Lee 1907), Tuerto Gravels (Stearn 1953), and Ortiz Gravels (Kelley and Northrop 1975) - also lies within $5 \mathrm{~km}$ of the village.

The most abundant and closest clay deposits to San Marcos Pueblo are weathering from the Espinaso Volcanics (Disbrow and Stoll 1957). Clay coming from some of these iron-rich outcrops fire red (Schleher 2010; Schleher et al. 2002). The clay colors of experimental tiles fired from these Espinaso Volcanics clays match pastes in pottery vessels made at San Marcos (Schleher et al. 2002); no yellow firing clays were identified. However, there are limited outcrops of the Mancos Group (including the Dakota Sandstone Subdivision) and the Mesa Verde Formation within $7 \mathrm{~km}$ of San Marcos Pueblo and extensive outcrops within $13 \mathrm{~km}$. Unfortunately, potentially yellow-firing clays from these outcrops were not accessible at the time this research was conducted.

It should be mentioned that other sites in the Galisteo Basin (including but not limited to Pueblo Blanco, Pueblo Galisteo, and San Lazaro Pueblo) have close and more extensive outcrops of the Mancos Group and Mesa Verde Formation than those at San Marcos Pueblo (Scholle 2003) and may also have been a source of yellow-firing clays. The Espinaso Volcanics also outcrop near some of these villages (Scholle 2003). For example, experimental tiles made from clays collected from the San Lazaro clay mine (Fenn 2004: 79) fire red. As observed by Schleher, these tiles 
match some glaze-on-yellow sherd pastes and may reflect production at San Lazaro Pueblo.

Overall, the geology of the study area is complex with limited research having been performed to characterize the clays of this region. As already mentioned, we know that Tunque and San Marcos Pueblos were the two major production centers for glaze-on-yellow pottery. As discussed below, we also know that finished vessels and lead to make glaze paint moved between these two villages. While we know that the yellow slip clays used on San Marcos pottery may have been collected from a number of different untested sources, we also know that three of the four yellow color groups identified on sherds produced at San Marcos Pueblo match the color groups observed on sherds produced at Tunque Pueblo. Overall, then, the experimental firing provided an initial indication in testing whether or not some of the slips applied to yellow-slipped vessels produced at San Marcos Pueblo could have originated near Tunque Pueblo. We decided to test this possibility further with chemical characterization. However, we see this research as one step in the study of interaction rather than a final explanation; we hope it will generate discussion and further research within the region.

\section{The Sample}

Our study used chemical characterization by LA-ICP-MS to examine 72 samples consisting of a combination of ceramic sherds, bricks, and ceramic tiles made from field clays (Table 1). In terms of ceramic sherds, we were specifically interested in yellow-slipped Rio Grande Glaze Ware types that were made at Tunque Pueblo and San Marcos Pueblo. Seventy years of extensive regional petrographic research on both decorated and utility wares provides confidence that production 
provenance can be determined for these two sites: pottery produced at Tunque Pueblo has a characteristically light-colored paste, is normally unslipped and polished, and is tempered with hornblende-latite ash (Warren 1969, 1979, 1981; Nelson and Habicht-Mauche 2006); pottery produced at San Marcos Pueblo has a dark gray or red paste, is yellow-slipped, and is tempered with weathered augitemonzonite (Nelson and Habicht-Mauche 2006; Schleher 2010; Warren 1979, 1981). Using these criteria, a sample of 31 sherds produced at and recovered from Tunque Pueblo was selected along with a sample of 28 sherds produced at and recovered from San Marcos Pueblo.

Six ceramic tiles made of field clay collected from the vicinity of Tunque Pueblo and seven bricks made at the historic Tonque Brick Works located along the west edge of the archaeological village were included for comparison with the archaeological ceramic samples. The Tonque Brick Works was established in 1909 and operated until 1942, resulting in the destruction of a portion of the archaeological site (Armstrong et al. 2011). The factory mined local clays; as discussed above, the resulting bricks vary in color from yellow to red. Modern access to the historic brick factory and the archaeological village is restricted and sampling is not permitted; however, prior to these restrictions, an avocational archaeologist (who has requested anonymity) collected clays and bricks. While the clays were collected from "all along the Hagen road just east of the ruin," the bricks were collected from the "spoils piles" at the abandoned factory. Although not ideal, this sample is currently the only comparative sample available for analysis and there is little reason to doubt its provenience. 
Table 1: The sample. Although there is debate as to how chronologically sensitive rim forms are, the designations Glaze A-F refer to differences in bowl rim forms that are commonly used to seriate Rio Grande Glaze Ware pottery (Eckert 2006).

\begin{tabular}{|c|c|c|c|c|}
\hline Sample ID & Provenience & sample type & Date & k-means cluster \\
\hline brick 1 & Tonque Brick Works & brick & Historic & 1 \\
\hline brick 2 & Tonque Brick Works & brick & Historic & 1 \\
\hline brick 3 & Tonque Brick Works & brick & Historic & 1 \\
\hline brick 4 & Tonque Brick Works & brick & Historic & 2 \\
\hline brick 5 & Tonque Brick Works & brick & Historic & 1 \\
\hline brick 6 & Tonque Brick Works & brick & Historic & 3 \\
\hline brick 7 & Tonque Brick Works & brick & Historic & 3 \\
\hline clay 1 & Tunque Pueblo - clay pit north & clay & Modern & 4 \\
\hline clay 2 & Tunque Pueblo - plaza & clay & Modern & 3 \\
\hline clay 3 & Tunque Pueblo - clay pit east & clay & Modern & 1 \\
\hline clay 4 & Tunque Pueblo - Hagan roadside & clay & Modern & 1 \\
\hline clay 5 & Tunque Pueblo - surface & clay & Modern & 5 \\
\hline clay 6 & Tunque Pueblo - surface & clay & Modern & 5 \\
\hline s3 & San Marcos Pueblo & Glaze B Largo Gl/y & AD $1410-1500+$ & 1 \\
\hline s4 & San Marcos Pueblo & Glaze A Cieneguilla Gl/y & AD 1321-1450+ & 2 \\
\hline s11 & San Marcos Pueblo & Glaze B Largo Gl/y & AD 1410-1500+ & 1 \\
\hline s12 & San Marcos Pueblo & Glaze A Cieneguilla Gl/y & AD 1321-1450+ & 1 \\
\hline s23 & San Marcos Pueblo & Glaze A Cieneguilla Gl/y & AD 1321-1450+ & 1 \\
\hline s24 & San Marcos Pueblo & Glaze A Cieneguilla Gl/y & AD 1321-1450+ & 1 \\
\hline s28 & San Marcos Pueblo & Glaze C Espinoso Gl/p & AD 1410-1600+ & 2 \\
\hline s30 & San Marcos Pueblo & Glaze C Espinoso Gl/p & AD 1410-1600+ & 2 \\
\hline s31 & San Marcos Pueblo & Glaze B Largo Gl/y & AD 1410-1500+ & 2 \\
\hline s33 & San Marcos Pueblo & Glaze A Cieneguilla Gl/y & AD 1321-1450+ & 2 \\
\hline s34 & San Marcos Pueblo & Glaze A Cieneguilla Gl/y & AD 1321-1450+ & 2 \\
\hline s36 & San Marcos Pueblo & Glaze B Largo Gl/y & AD 1410-1500+ & 2 \\
\hline s37 & San Marcos Pueblo & Glaze B Largo Gl/y & AD 1410-1500+ & 2 \\
\hline s46 & San Marcos Pueblo & Glaze A Cieneguilla Gl/y & AD 1321-1450+ & 2 \\
\hline s48 & San Marcos Pueblo & Glaze C Espinoso Gl/p & AD 1410-1600+ & 2 \\
\hline s50 & San Marcos Pueblo & Glaze A Cieneguilla Gl/y & AD 1321-1450+ & 2 \\
\hline s56 & San Marcos Pueblo & Glaze B Largo Gl/y & AD 1410-1500+ & 2 \\
\hline s57 & San Marcos Pueblo & Glaze A Cieneguilla Gl/y & AD 1321-1450+ & 2 \\
\hline s65 & San Marcos Pueblo & Glaze A Cieneguilla Gl/y & AD 1321-1450+ & 2 \\
\hline s68A & San Marcos Pueblo & Glaze A Cieneguilla Gl/y & AD 1321-1450+ & 2 \\
\hline s68C & San Marcos Pueblo & Glaze C Espinoso Gl/y & AD 1410-1600+ & 2 \\
\hline s70A & San Marcos Pueblo & Glaze A Cieneguilla Gl/y & AD 1321-1450+ & 2 \\
\hline s70B & San Marcos Pueblo & Glaze B Largo Gl/p & AD 1410-1500+ & 2 \\
\hline s71 & San Marcos Pueblo & Glaze A Cieneguilla Gl/y & AD 1321-1450+ & 2 \\
\hline s76 & San Marcos Pueblo & Glaze A Cieneguilla Gl/y & AD 1321-1450+ & 1 \\
\hline s78 & San Marcos Pueblo & Glaze A Cieneguilla Gl/y & AD 1321-1450+ & 2 \\
\hline s79A & San Marcos Pueblo & Glaze A Cieneguilla Gl/y & AD 1321-1450+ & 2 \\
\hline s79B & San Marcos Pueblo & Glaze B Largo Gl/y & AD 1410-1500+ & 2 \\
\hline t3 & Tunque Pueblo & Glaze B Largo Gl/p & AD 1410-1500+ & 1 \\
\hline $\mathrm{t} 4$ & Tunque Pueblo & Glaze D San Lazaro Gl/p & AD 1460-1550+ & 3 \\
\hline t5 & Tunque Pueblo & Glaze B Largo Gl/p & AD 1410-1500+ & 2 \\
\hline t6C & Tunque Pueblo & Glaze C Espinoso Gl/p & AD 1410-1600+ & 4 \\
\hline t6A & Tunque Pueblo & Glaze A Cieneguilla Gl/p & AD 1321-1450+ & 4 \\
\hline t7 & Tunque Pueblo & Glaze D San Lazaro Gl/p & AD 1460-1550+ & 4 \\
\hline t8 & Tunque Pueblo & Glaze C Espinoso Gl/p & AD 1410-1600+ & 4 \\
\hline t9 & Tunque Pueblo & Glaze D San Lazaro Gl/p & AD 1460-1550+ & 3 \\
\hline t10 & Tunque Pueblo & Glaze C Espinoso Gl/p & AD 1410-1600+ & 4 \\
\hline t11 & Tunque Pueblo & Glaze D San Lazaro Gl/p & AD 1460-1550+ & 4 \\
\hline t12 & Tunque Pueblo & Glaze C Espinoso Gl/p & AD 1410-1600+ & 4 \\
\hline t13 & Tunque Pueblo & Glaze D San Lazaro Gl/p & AD 1460-1550+ & 3 \\
\hline t14 & Tunque Pueblo & Glaze D San Lazaro Gl/p & AD 1460-1550+ & 4 \\
\hline t15 & Tunque Pueblo & Glaze A Cieneguilla Gl/p & AD 1321-1450+ & 5 \\
\hline t16 & Tunque Pueblo & Glaze E Puaray Gl/p & AD 1480-1630+ & 4 \\
\hline t17 & Tunque Pueblo & Glaze A Cieneguilla Gl/y & AD 1321-1450+ & 4 \\
\hline t18 & Tunque Pueblo & Glaze C Espinoso Gl/p & AD 1410-1600+ & outlier - removed \\
\hline t19 & Tunque Pueblo & Glaze D San Lazaro Gl/p & AD 1460-1550+ & 1 \\
\hline t20 & Tunque Pueblo & Glaze D & AD 1460-1550+ & 4 \\
\hline t21 & Tunque Pueblo & Glaze A Cieneguilla Gl/p & AD 1321-1450+ & 4 \\
\hline t22 & Tunque Pueblo & Glaze D San Lazaro Gl/p & AD $1460-1550+$ & 4 \\
\hline t23 & Tunque Pueblo & Glaze C/D & AD 1410-1600+ & 4 \\
\hline t24 & Tunque Pueblo & Glaze D San Lazaro Gl/p & AD 1460-1550+ & 5 \\
\hline t25 & Tunque Pueblo & Glaze D San Lazaro Gl/p & AD 1460-1550+ & 4 \\
\hline
\end{tabular}


Glaze C Espinoso Gl/p

Glaze D San Lazaro G1/p

Glaze C Espinoso G1/p

Glaze B Largo Gl/p

Glaze D San Lazaro Gl/p

Glaze A Cieneguilla Gl/p

Glaze C Espinoso Gl/p
AD 1410-1600+

AD 1460-1550+

AD 1410-1600+

AD 1410-1500+

AD 1460-1550+

AD 1321-1450+

AD 1410-1600+

Various sociopolitical, curatorial, and economic factors limited our initial access to archaeological ceramic samples for destructive analysis and access to clay and brick samples. Methodologically, then, our sample is not ideal in terms of size or selection technique. While these conditions were less than optimal for standard ceramic characterization studies, our results presented below provide potentially significant implications for interpreting social networks between communities of potters. We hope that these preliminary results encourage other researchers to pursue similar provenance studies of pottery slips from this and other regions of the Southwest using larger and more robust samples. We also hope that our study can serve as a model for researchers, regardless of the region in which they work, who are hesitant to perform analyses on less-than-ideal assemblages. Exploring data patterns while recognizing sampling constraints allows us to broaden our analyses to include the many archaeological collections in museums with various methodological limitations, in turn allowing us to tentatively broaden our interpretations of past human behavior.

\section{LA-ICP-MS Methodology and Statistical Analyses}

LA-ICP-MS is a microprobe technique determined to be appropriate for this study because, unlike bulk analyses more suitable for homogenous materials, LAICP-MS allows for characterization of specific components of heterogeneous materials (Cogswell et al. 2005; Neff 2003). In this case we focused on characterizing clays used for ceramic slips and compared them to bulk raw clay and historic 
bricks; the strength of the technique is that it allowed us to target clay particles in each sample while ignoring non-plastic inclusions and so we could control for the issue of differences in original material preparation. LA-ICP-MS analyses were conducted on a Perkin Elmer Elan DRCII housed at the Elemental Analysis Laboratory, Department of Chemistry, Texas A\&M University under the direction of Dr. William Dennis James.

A New Wave UP-213 laser ablation system with associated software was used for sample induction. At the start of each batch of 10 samples, a series of standards were analyzed: NIST standard SRM 610, NIST standard SRM 612, Glass Buttes obsidian, Pachuca obsidian, and MURR's Ohio Red Clay. A blank (the machine was run with no sample) was also run prior to each batch. The standards and blank runs were used to calibrate data using the Gratuze method discussed below (Gratuze 1999; Neff 2003; Speakman and Neff 2005). Prior to the analyses, the following parameters were set: the diameter of the laser beam was adjusted to 30 $\mu \mathrm{m}$; each pass of the laser over the sample would remove approximately $5 \mu \mathrm{m}$ of material; the repetition rate of the laser was set to $10 \mathrm{~Hz}$; and the maximum energy of the beam was set to $70 \%$. A laser pass pattern was customized for each sample to avoid non-plastic inclusions. After an initial pass over a surface to remove possible surface contaminants, a second ablation pass was needed to generate abundance data for 38 elements.

Raw count elemental signals collected from the LA-ICP-MS analyses were quantified using an approach outlined by Gratuze and colleagues (2001). The formulas for this approach are explained and provided by both Neff (2003) and Speakman and Neff (2005). Briefly put, the approach corrects for background noise, 
standardizes by calculating a ratio to the counts for a single element (in our case, $\mathrm{Al}$ ), and converts elemental signals to signals of their oxides. These signals are then converted to oxide concentrations, with a result that the sum of the oxide concentrations within each sample will equal 100. The assumption underlying this quantification is that all elements being measured represent all of the material, other than oxygen, that is ablated from the samples. This assumption may introduce some error for elements that occur in more than one oxidation state and ignores any water that may have been in the sample. Overall, however, experiments on a range of materials, including ceramic, have shown that this approach yields results in reasonable agreement with data generated by other geochemical techniques (Neff 2003; Speakman and Neff 2005). Oxide concentrations were then log base-10 transformed so as to scale the dataset to a similar order of magnitude to account for differences in concentration between major and trace elements as well as to produce a more nearly normal distribution (Baxter 2003).

Three techniques were used to explore patterning in the data and create statistically defensible and archaeologically interpretable groupings: principal components analysis (PCA), k-means clustering, and bivariate plots. Although not the only statistical methods used in compositional studies (Baxter 2003; Bishop et al. 1982), these techniques are commonly used and were selected as the best suite of techniques given our sample size. Statistics were performed using XLSTAT 19.4. PCA (Shennan 1997) compresses a large number of variables into a smaller number of uncorrelated variables called principal components (PC); the first principal component accounts for as much of the variability as possible, and each remaining component accounts for as much of the remaining variability as possible. 
$\mathrm{K}$-means cluster analysis (Baxter 2003) is a non-hierarchical clustering method used for grouping cases; its advantage over other clustering methods is that as a non-hierarchal technique it minimizes intracluster variation while maximizing intercluster variation. The cluster solution with the greatest difference between the average sum of the squared distances for randomly generated data and the original data is considered to be the "best" cluster solution (Kintigh and Ammerman 1982). Bivariate plots provide an easy means to visually examine the relationship between any two elements and helps in exploring which elements may be driving separation into compositional groups.

\section{Results}

One sherd (t18) recovered from Tunque Pueblo consistently appeared as an anomaly during initial statistical analyses. This sample was relatively high in $\mathrm{Ca}$, $\mathrm{Cu}, \mathrm{Zn}$ and $\mathrm{Sr}$ when compared to the dataset as a whole. It may reflect a clay source that our study did not sample or it may reflect a vessel produced at a different village. Alternatively, this sherd may reflect sampling error during the LA-ICP-MS analysis in which the analyst accidentally sampled a portion of a non-plastic inclusion. Without further data, it is impossible to evaluate these options further; this sherd was considered an outlier and was removed from the dataset in the below analysis.

PCA was run on transformed but unstandardized data to highlight the minor and trace element optimizing the ability to identify different clays from a similar resource procurement area (Baxter 2003:78). The first two principal components account for $54.6 \%$ of the variability observed in the LA-ICP-MS analyses, while the 
Figure 2: First two components of PCA on $\log 10$ oxide concentrations for 71 samples. Ceramic samples from San Marcos Pueblo plot primarily in the upper left of the graph, while ceramic samples from Tunque Pueblo plot primarily in the lower right.
O brick
- clay
San Marcos sherd
- Tunque sherd

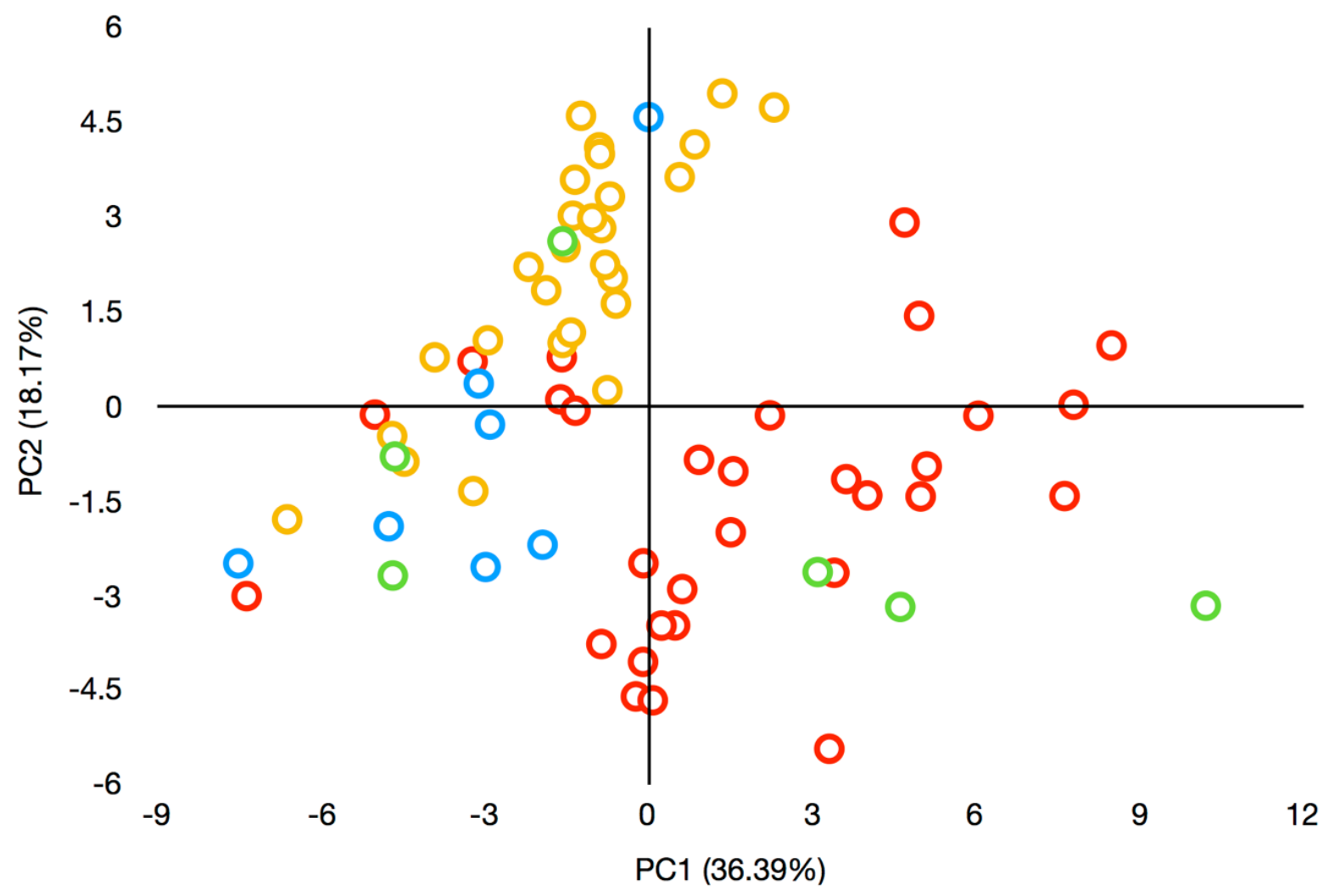

first three components account for $62.5 \%$. Samples plotted by provenience (Figure 2) show a segregation of sherds recovered from the two villages: sherds recovered from Tunque Pueblo group primarily in the lower half of the graph, especially in the lower right portion; sherds recovered from San Marco Pueblo group primarily in the upper half of the graph, especially in the upper left portion. Most of the Tunque Pueblo sherds group with two clays; while most of the San Marcos sherds group with a clay and a brick. The greater chemical diversity in the brick and clay samples when 
Table 2: Summary of k-means 5-cluster solution.

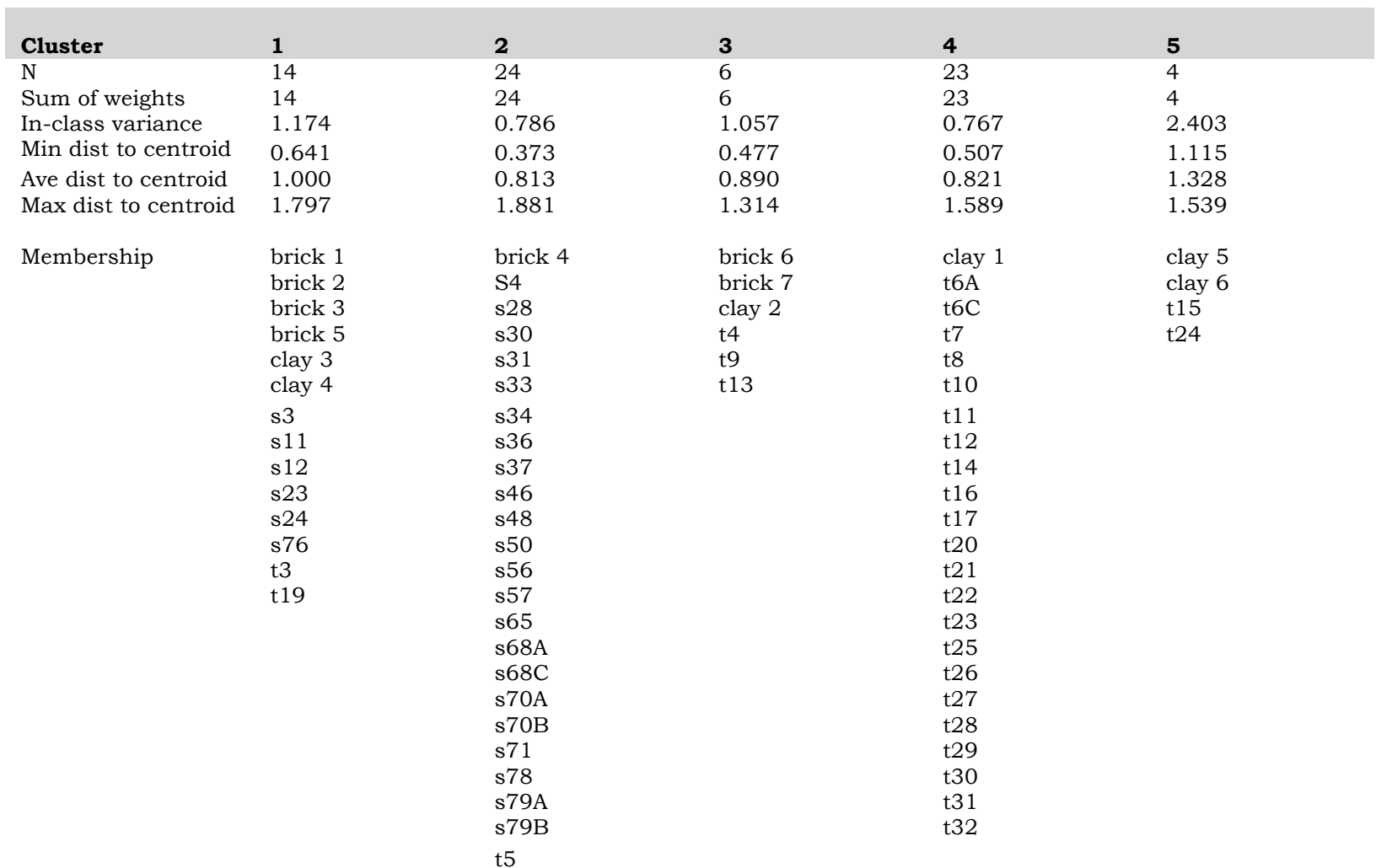

Mean \pm SD of oxide concentrations

\begin{tabular}{|c|c|}
\hline $\mathrm{Na} 23$ & $00.6562 \pm 0.3954$ \\
\hline Mg24 & $01.9114 \pm 0.9358$ \\
\hline $\mathrm{A} 127$ & $18.6262 \pm 8.4417$ \\
\hline $\operatorname{Si} 29$ & $63.8461 \pm 7.6352$ \\
\hline K39 & $02.1547 \pm 0.5776$ \\
\hline $\mathrm{Ca} 44$ & $08.2545 \pm 6.4661$ \\
\hline $\operatorname{Sc} 45$ & $00.0014 \pm 0.0009$ \\
\hline Ti47 & $00.7103 \pm 0.1978$ \\
\hline V51 & $00.0092 \pm 0.0017$ \\
\hline Cr52 & $00.0064 \pm 0.0016$ \\
\hline Mn55 & $00.0288 \pm 0.0143$ \\
\hline Fe57 & $03.3838 \pm 0.9347$ \\
\hline Co59 & $00.0008 \pm 0.0003$ \\
\hline Ni60 & $00.0025 \pm 0.0007$ \\
\hline Cu65 & $00.0034 \pm 0.0030$ \\
\hline Zn66 & $00.0196 \pm 0.0130$ \\
\hline $\mathrm{Rb} 85$ & $00.0075 \pm 0.0021$ \\
\hline Sr88 & $00.0234 \pm 0.0110$ \\
\hline Zr90 & $00.0144 \pm 0.0108$ \\
\hline Ba138 & $00.0456 \pm 0.0323$ \\
\hline La139 & $00.0027 \pm 0.0009$ \\
\hline $\mathrm{Ce} 140$ & $00.0058 \pm 0.0021$ \\
\hline $\operatorname{Pr} 141$ & $00.0006 \pm 0.0002$ \\
\hline $\mathrm{Nd} 142$ & $00.0024 \pm 0.0007$ \\
\hline Sm 152 & $00.0004 \pm 0.0001$ \\
\hline Eu 153 & $00.0001 \pm 3.0 \mathrm{E}-5$ \\
\hline Gd 158 & $00.0003 \pm 0.0001$ \\
\hline Tb159 & $00.0001 \pm 1.4 \mathrm{E}-5$ \\
\hline Dy 164 & $00.0003 \pm 0.0001$ \\
\hline Ho165 & $00.0001 \pm 1.4 \mathrm{E}-5$ \\
\hline $\operatorname{Er} 166$ & $00.0002 \pm 3.5 \mathrm{E}-5$ \\
\hline $\operatorname{Tm} 169$ & $02.3 \mathrm{E}-5 \pm 5.5 \mathrm{E}-6$ \\
\hline Yb174 & $00.0002 \pm 4.6 \mathrm{E}-5$ \\
\hline Lu175 & $02.5 \mathrm{E}-5 \pm 5.2 \mathrm{E}-6$ \\
\hline Hf180 & $00.0003 \pm 0.0002$ \\
\hline
\end{tabular}

$00.5603 \pm 0.3359 \quad 00.5121 \pm 0.2032$ $01.7148 \pm 0.4589$ $20.8837 \pm 2.4553$ $61.4002 \pm 3.8417$ $03.2026 \pm 0.6639$ $06.8998 \pm 4.0566$ $00.0014 \pm 0.0004$ $00.6605 \pm 0.0958$ $00.0084 \pm 0.0008$ $00.0034 \pm 0.0017$ $00.0786 \pm 0.0246$ $03.0992 \pm 0.6709$ $00.0014 \pm 0.0018$ $00.0028 \pm 0.0011$ $00.0078 \pm 0.0039$ $00.0685 \pm 0.0460$ $00.0090 \pm 0.0015$ $00.0323 \pm 0.0170$ $00.0173 \pm 0.0186$ $00.0436 \pm 0.0238$ $00.0029 \pm 0.0004$ $00.0085 \pm 0.0130$ $00.0006 \pm 0.0001$ $00.0025 \pm 0.0004$ $00.0005 \pm 0.0001$ $00.0001 \pm 1.9 \mathrm{E}-5$ $00.0004 \pm 0.0001$ $00.0001 \pm 1.1 \mathrm{E}-5$ $00.0003 \pm 0.0001$ $00.0001 \pm 1.0 \mathrm{E}-5$ $00.0002 \pm 3.1 \mathrm{E}-5$ $02.7 \mathrm{E}-5 \pm 4.9 \mathrm{E}-6$ $00.0002 \pm 4.1 \mathrm{E}-5$ $02.9 \mathrm{E}-5 \pm 5.5 \mathrm{E}-6$ $00.0003 \pm 0.0001$ $01.8957 \pm 0.5515$ $17.1344 \pm 4.2800$ $66.5916 \pm 3.2765$ $02.0205 \pm 0.4026$ $07.4383 \pm 3.6815$ $00.0011 \pm 0.0002$ $00.6245 \pm 0.1477$ $00.0094 \pm 0.0008$ $00.5 \mathrm{E}-8 \pm 1.9 \mathrm{E}-9$ $00.0479 \pm 0.0343$ $03.4522 \pm 0.9737$ $00.0011 \pm 0.0005$ $00.0026 \pm 0.0007$ $00.0028 \pm 0.0011$ $00.0395 \pm 0.0398$ $00.0069 \pm 0.0007$ $00.0416 \pm 0.0244$ $00.0108 \pm 0.0040$ $00.1096 \pm 0.0816$ $00.0022 \pm 0.0002$ $00.0047 \pm 0.0004$ $00.0005 \pm 4.3 \mathrm{E}-5$ $00.0020 \pm 0.0001$ $00.0004 \pm 3.0 \mathrm{E}-5$ $00.0001 \pm 6.8 \mathrm{E}-6$ $00.0003 \pm 3.1 \mathrm{E}-5$ $05.0 \mathrm{E}-5 \pm 5.1 \mathrm{E}-6$ $00.0003 \pm 3.2 \mathrm{E}-5$ $00.0001 \pm 7.5 \mathrm{E}-6$ $00.0001 \pm 2.1 \mathrm{E}-5$ $02.3 \mathrm{E}-5 \pm 4.2 \mathrm{E}-6$ $00.0002 \pm 3.2 \mathrm{E}-5$ $02.4 \mathrm{E}-5 \pm 5.2 \mathrm{E}-6$ $00.0002 \pm 0.0001$
$01.1901 \pm 0.3227$ $02.1398 \pm 1.0151$ $26.7465 \pm 2.3069$ $58.0690 \pm 3.1145$ $02.0590 \pm 0.5185$ $04.2353 \pm 1.9100$ $00.0008 \pm 0.0001$ $00.6517 \pm 0.1211$ $00.0051 \pm 0.0011$ $00.0025 \pm 0.0010$ $00.0261 \pm 0.0095$ $02.7349 \pm 0.5900$ $00.0003 \pm 0.0001$ $00.0009 \pm 0.0009$ $00.0099 \pm 0.0069$ $00.0273 \pm 0.0145$ $00.0051 \pm 0.0014$ $00.0314 \pm 0.0124$ $00.0185 \pm 0.0044$ $00.0243 \pm 0.0144$ $00.0045 \pm 0.0023$ $00.0090 \pm 0.0039$ $00.0009 \pm 0.0003$ $00.0032 \pm 0.0013$ $00.0005 \pm 0.0001$ $00.0001 \pm 1.5 \mathrm{E}-5$ $00.0004 \pm 0.0001$ $00.0001 \pm 1.2 \mathrm{E}-5$ $00.0003 \pm 0.0001$ $00.0001 \pm 1.4 \mathrm{E}-5$ $00.0002 \pm 4.1 \mathrm{E}-5$ $02.7 \mathrm{E}-5 \pm 6.6 \mathrm{E}-6$ $00.0002 \pm 0.0001$ $03.1 \mathrm{E}-5 \pm 8.6 \mathrm{E}-6$ $00.0004 \pm 0.0001$
$00.5205 \pm 0.1290$ $02.1412 \pm 0.4996$ $32.6180 \pm 2.6750$ $57.0650 \pm 2.6692$ $02.1091 \pm 1.0013$ $02.3523 \pm 1.4855$ $00.0005 \pm 0.0001$ $00.5330 \pm 0.0603$ $00.0023 \pm 0.0006$ $00.0008 \pm 0.0003$ $00.0115 \pm 0.0105$ $01.9050 \pm 0.3485$ $00.0002 \pm 0.0001$ $00.0007 \pm 0.0001$ $00.0030 \pm 0.0034$ $00.0152 \pm 0.0160$ $00.0014 \pm 0.0015$ $00.0216 \pm 0.0100$ $00.0235 \pm 0.0065$ $00.0190 \pm 0.0296$ $00.0053 \pm 0.0019$ $00.0121 \pm 0.0045$ $00.0010 \pm 0.0003$ $00.0039 \pm 0.0010$ $00.0007 \pm 0.0001$ $00.0001 \pm 7.2 \mathrm{E}-6$ $00.0005 \pm 4.5 \mathrm{E}-5$ $00.0001 \pm 6.0 \mathrm{E}-6$ $00.0004 \pm 3.0 \mathrm{E}-5$ $00.0001 \pm 7.1 \mathrm{E}-6$ $00.0002 \pm 3.0 \mathrm{E}-5$ $03.5 \mathrm{E}-5 \pm 5.4 \mathrm{E}-6$ $00.0003 \pm 0.0001$ $03.8 \mathrm{E}-5 \pm 1.1 \mathrm{E}-6$ $00.0006 \pm 0.0001$ 
$00.0001 \pm 3.6 \mathrm{E}-5$ $00.0021 \pm 0.0006$ $00.0009 \pm 0.0004$
$00.0002 \pm 3.4 \mathrm{E}-5$

$00.0032 \pm 0.0006$ $00.0014 \pm 0.0005$

compared to the pottery samples suggests that the geology of the Tunque area is diverse but potters were only selecting a subsample of available clays for pottery production. This selectiveness on the part of potters is no surprise, but needs to be remembered in future studies of the region; the presence of clay near a site does not necessarily mean the use of that clay by potters.

A k-means 5-cluster solution (Table 2) was determined to be the best cluster solution (Kintigh and Ammerman 1982). This solution groups the assemblage with the largest cluster $(\mathrm{N}=24)$ dominated by samples from San Marcos Pueblo and the other large cluster $(\mathrm{N}=23)$ dominated by samples from Tunque Pueblo. Both of these large clusters also contain one brick or clay sample. Samples plotted by k-means 5cluster solution using the first two PCA components show comfortable agreement between the two methods (Figure 3).

Not surprisingly given their geological proximity, there is a great deal of chemical similarity between the clays, bricks, and sherds produced at Tunque Pueblo; yellow slips on the sherds produced at San Marcos Pueblo share in that similarity. Bivariate plots help visualize that clusters are driven by differences in Mn, Cr, Pr, Th, and U (Figures 4 and 5; see also Table 2); for example, cluster 4 samples have relatively low $\mathrm{Mn}$ concentrations and high $\mathrm{U}$ concentrations when compared to cluster 2 samples, while cluster 2 samples have relatively high $\mathrm{Mn}$ concentrations and low $\mathrm{Cr}$ concentrations when compared to cluster 1 samples. Clay 1 and the majority $(\mathrm{N}=23$ ) of Tunque sherds group together into Cluster 4 . Cluster 4 has relatively low concentrations of $\mathrm{Mn}$ and $\mathrm{Cr}$, and high concentrations of $\mathrm{U}, \mathrm{Pr}$ 
Figure 3: First two components of PCA plotted by k-means 5 cluster solution.

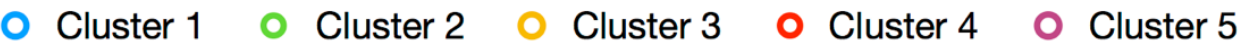

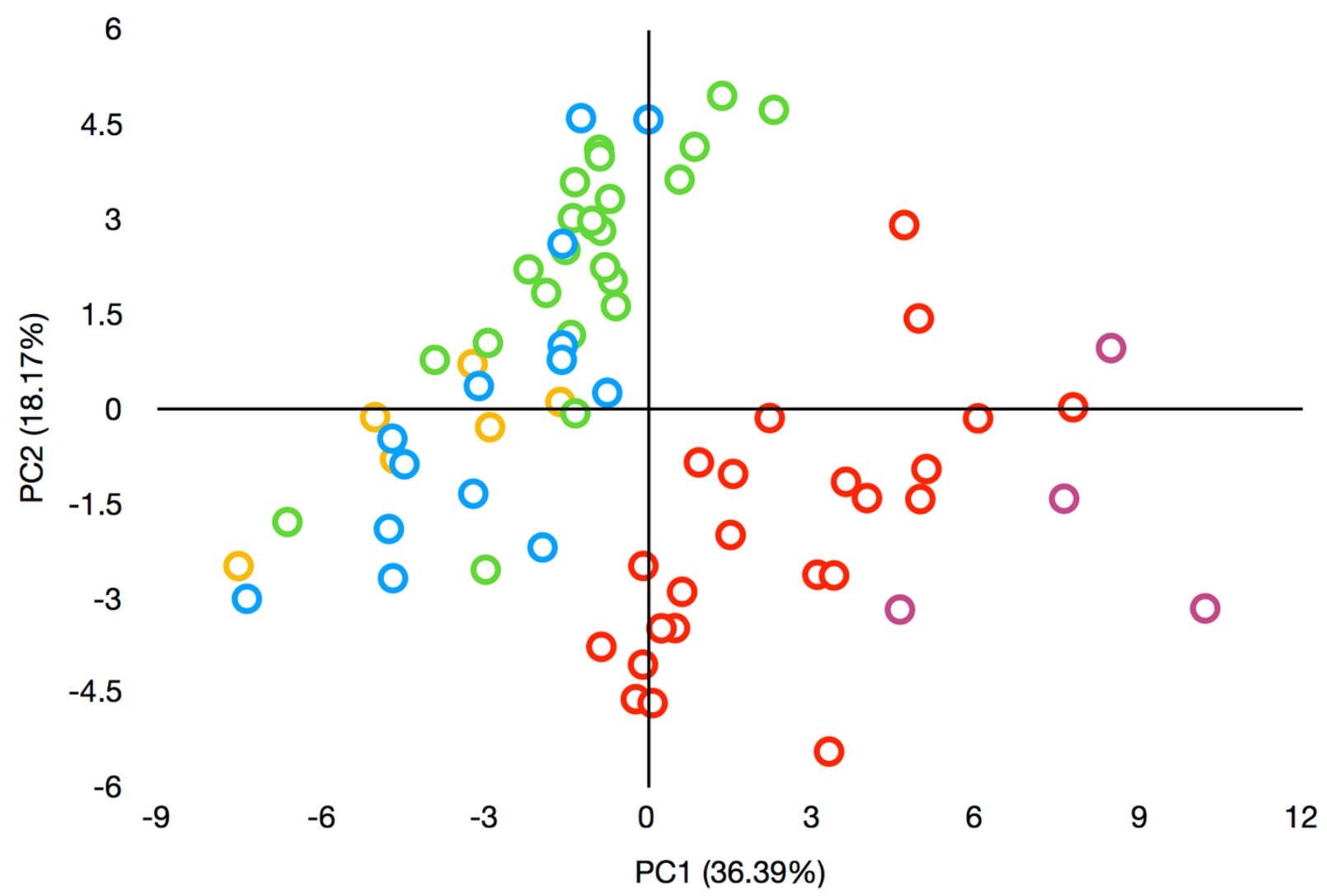

and Th when compared to other clusters. In other words, sherds collected during the excavation of Tunque Pueblo can be matched compositionally to a specific clay sample collected in the vicinity of the village. Clusters 3 and 5 also contain sherds from Tunque Pueblo as well as local brick and clay samples, suggesting that Tunque potters were using a variety of locally available clays to form their vessels. This is not really surprising, as archaeologists have suspected for a long time that clays used by Tunque potters were collected from the same area as the clays used by the historic Tonque Brick Works.

All of the San Marcos sherds $(N=30)$, three Tunque sherds, and the remainder of the bricks and clay samples group into Cluster 1 and 2 . 
Figure 4: Bivariate plot of Mn55 and U238 oxide concentrations plotted by k-means 5 -cluster solution.

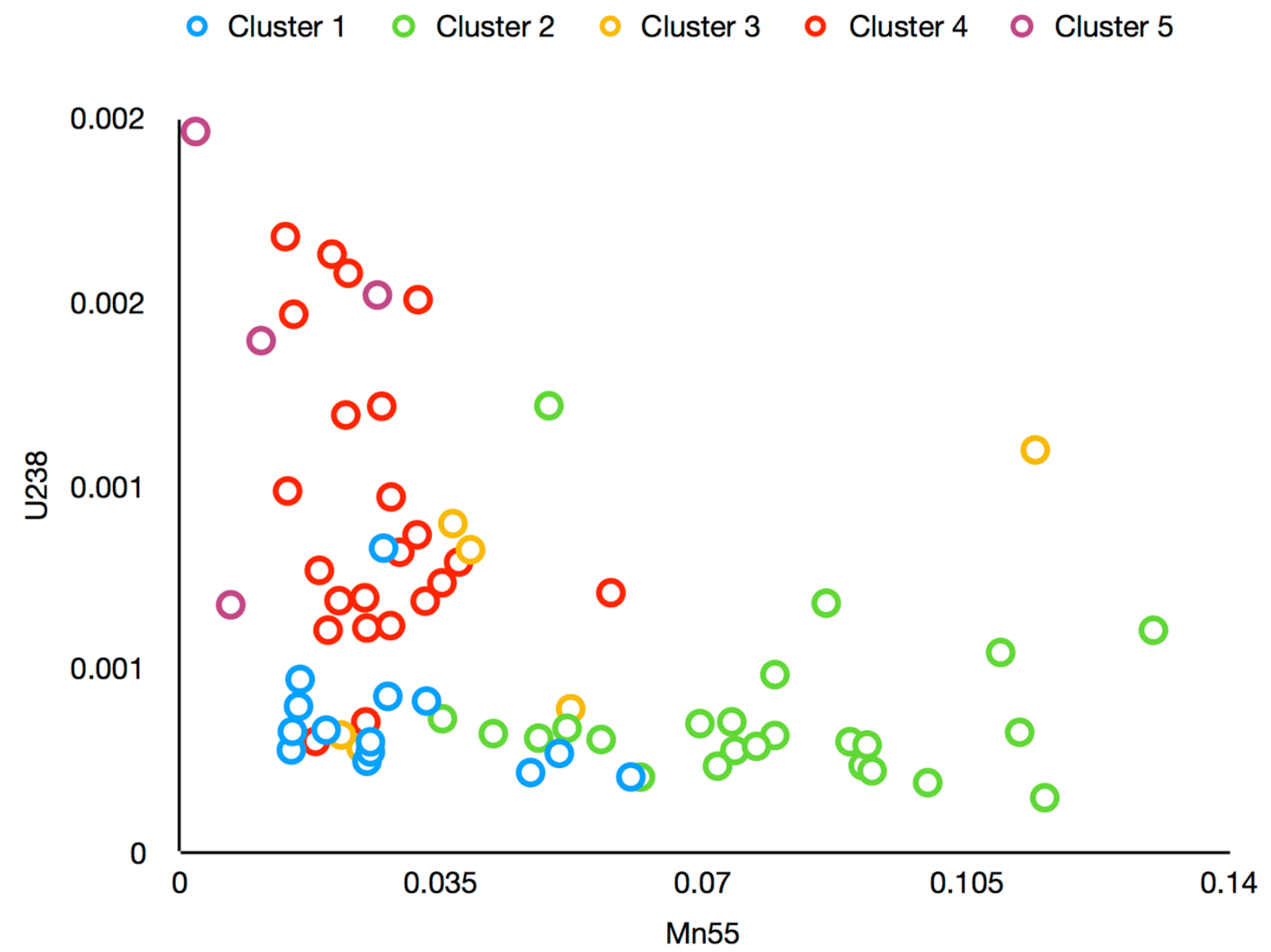

Interpretatively, it would seem that San Marcos potters were using clays that were available from near Tunque Pueblo to slip their vessels, but it was a different subset of clays than the Tunque potters favored to produce their own yellow-bodied vessels. This result probably speaks to the nature of the different clays available near Tunque Pueblo; while only a subset of those clays fired to the appropriate range of color desired by the potters, only a subset of that subset may have been appropriate to build a vessel. In other words, the characteristics of a clay required to produce a vessel are different than the characteristics of a clay required to slip a vessel. Tunque residents were not only aware of these differences, but were reserving 
Figure 5: Bivariate plot of $\mathrm{Cr} 52$ and $\operatorname{Pr} 141$ oxide concentrations plotted by k-means 5 -cluster solution.

- Cluster $1 \circ$ Cluster $2 \circ$ Cluster $3 \circ$ Cluster $4 \circ$ Cluster 5

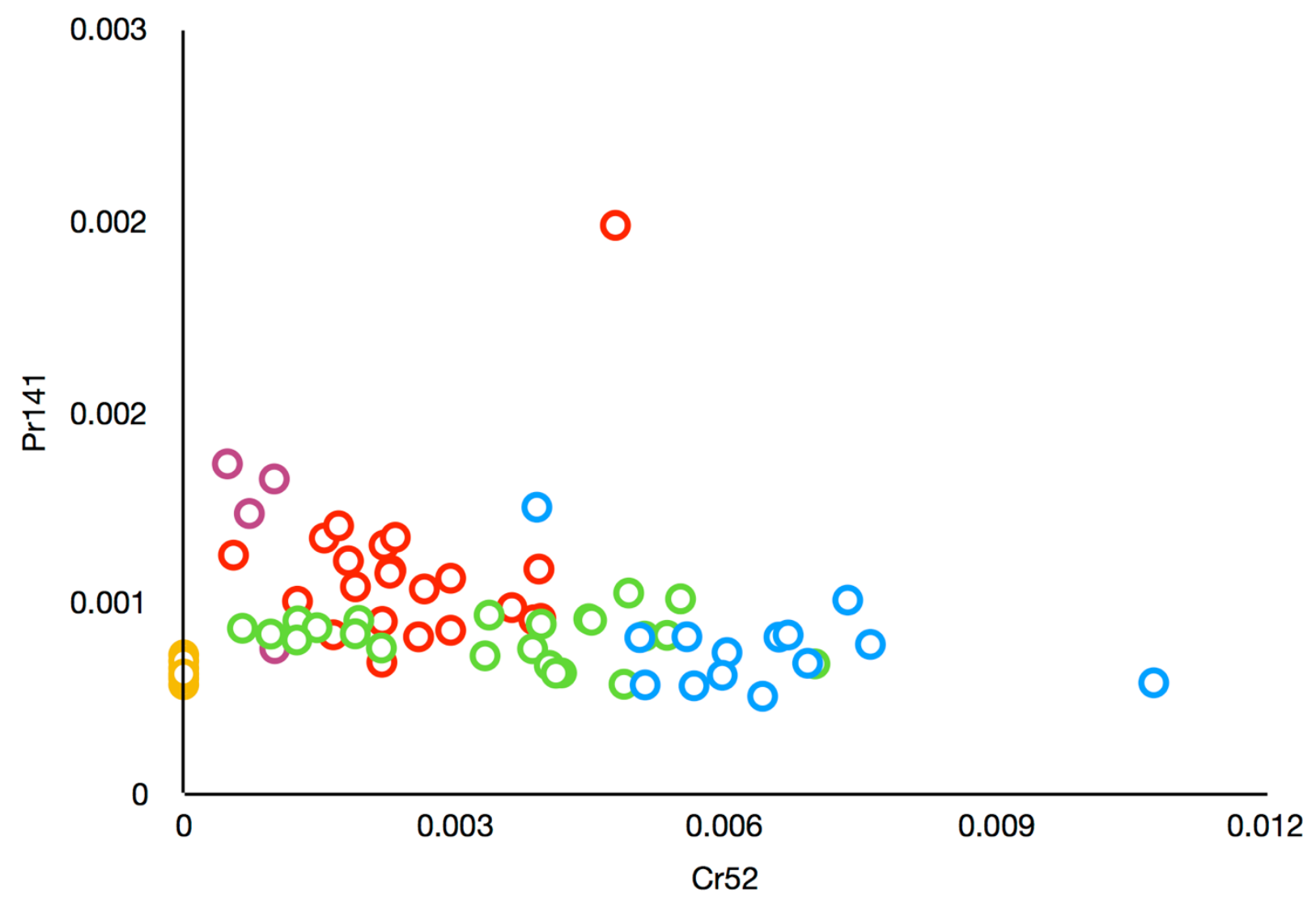

specific body clays for their own pottery production, while making the other yellowfiring clays available to potters from other villages for use as a slip.

\section{Discussion}

We argue both San Marcos and Tunque potters were using yellow-firing clays available from the vicinity of Tunque Pueblo, but they were using these clays in different ways. Tunque potters were making yellow-bodied, self-slipped vessels with a subset of locally available clays; San Marcos potters were using a different subset of clays from the Tunque vicinity as a yellow slip on their red-bodied vessels. In other words, although potters at these two villages were using distinctive production 
techniques, they were both incorporating clays available from Tunque Pueblo into their vessels. Similarly, potters at both villages were using the same lead source near San Marcos Pueblo (Habicht-Mauche et al. 2000, 2002; Nelson and HabichtMauche 2006; Huntley et al. 2007; Huntley 2008) and the same glaze recipes (Schleher et al. 2012) to make their paint. It is tempting to speculate that San Marcos residents controlled access to lead ore for glaze paints while Tunque residents restricted access to yellow slip clays. However, the story may not have been that straightforward: we know there are probably other sources of yellow firing clay available to San Marcos potters, including from the not-so-distant San Pedro district (Shepard 1942); further, there was lead available from the Placitas source immediately adjacent to Tunque Pueblo (Nelson and Habicht-Mauche 2006). So the question is not simply one of access.

Historically, resources for pottery production moved between Pueblo villages and between families of potters at different villages. Dillingham (1992:47) noted that "Acoma and Laguna potters have traded their desirable, fine white slip with craftspeople from Zuni". Parsons (1932:351) observed that Isleta potters "still buy their paints from the Laguna colonists" [at Isleta], which are obtained from localities near Old Laguna. Further, in the 1920s, a Tewa-speaking potter from Santa Clara Pueblo, Monica Silva, married into Keresan Santo Domingo Pueblo (Crane 1928:243). Her children at Santo Domingo Pueblo retain kin ties with Santa Clara to this day, bringing red slip clay to potters of their mother's lineage there (personal communication to Snow, name withheld by request; also see LeFree 1975:21). We argue that the movement of slip clays and glaze paints between San Marcos Pueblo and Tunque Pueblo may reflect similar scenarios during the late prehispanic and 
early colonial eras.

It is interesting to note that decorated vessels were also moving between San Marcos Pueblo and Tunque Pueblo (Warren 1979, 1981; Nelson and HabichtMauche 2006; Schleher 2010); for example, approximately 9\% of glaze ware sherds recovered from San Marcos were made at Tunque Pueblo (Schleher, personal observation). While this level of pottery exchange between villages was not insignificant, it suggests that the social network through which this pottery was moving had to have been of an altogether different type and scale than the one used to obtain slip clay required to make much of the yellow-slipped pottery at San Marcos over the almost 400 years of glaze ware production. Nelson and HabichtMauche (2006) have argued previously that within north central New Mexico glaze ware pots circulated among communities that shared a similar ethnolinguistic identity, most likely as a result of pot-luck style feasting and other inter-community activities. More specialized resources, such as lead for glaze-paint and slip clays, appear to have circulated differently, linking households across these ethnolinguistic clusters into much broader networks of regional interactions. The movement of these more specialized ceramic resources may reflect the kinds of eclectic and historically contingent, kin-based relationships between households from different ethnolinguistic villages recorded ethnographically and outlined above.

By producing pottery using resources obtained from multiple sources, potters may not only have been affirming social ties but were literally tying their pottery vessels to a broader social and cosmological landscape. Potters who produced vessels with clay from one village, but decorated with slip clay or lead for glaze-paint from the other village, would have been creating vessels that physically embodied 
the potter's social world. In addition, specific resources may also have been connected to historically and cosmologically significant places on the landscape making them embodiments of a community-centered historic and mythic world. If such were the case, then the exchange of finished pottery between communities may have been of less significance to the creation of enduring regional social networks than the acquisition of specific ceramic resources required to produce pottery.

\section{Conclusions}

The results of the current study, as well as previous studies of the circulation of lead for glaze-paint production in this same region (Habicht-Mauche et al. 2000, 2002; Huntley et al. 2007; Huntley 2008; Nelson and Habicht-Mauche 2006), suggest that inter-community ties as reflected in resource procurement were amazingly stable through time. But this project is only one of a suite of projects attempting to understand the movement of different types of resources up and down the Rio Grande valley. Once completed, these studies will need to be synthesized to create a broader understanding of the nature of different scales of social networks at play in this period of ethnogenesis. In developing such a synthesis, we suggest that Whiteley's concept of 'relationality' may be of great value (Whiteley 2004). Physical access to material resources may have been of far less significance than perceptions of exchange dependencies. Social fictions about the adequacy of specific resources might have played a role in the genesis of identity on the one hand, and the development of exchange networks on the other. For example, making yellow-slipped pottery may have been an important ethnic marker for San Marcos potters, but the yellow slip clay may also have had to have originated from Tunque Pueblo. As Whiteley explains (2004: 149), such social fictions preserve exchange dependencies 
because difference must be "established or recognized as a means for exchange, and thereby alliance, producing distinctions at one level simultaneous with identity at another."

\section{Acknowledgements}

Thank you needs to go to: Gretchen Obenauf and Joan Mathien (Albuquerque Archaeological Society), and Bruce Huckell and David Phillips (Maxwell Museum of Anthropology), for access to the Tunque material; Ann Ramenofsky (University of New Mexico) for access to the San Marcos sherds; Judith Habicht-Mauche (University of California, Santa Cruz) and Jun Sunseri (University of California, Berkeley) for editing and insight; William D. James (retired, Texas A\&M University) for access to his facilities; Hector Neff (University of California, Los Angeles) for help with LA-ICP-MS methodology; and Hayward Franklin and John Guthe for help with samples. Of course, any and all errors are our own.

\section{References Cited}

Armstrong, Karen, Thomas M. Morales and David H. Snow

2011 Tunque Redux: A Work in Progress. In Words and Sherds: Papers in Honor of Meliha S. Duran edited by E. J. Brown, C. J. Condie, and H. K. Crotty, pp. 33-42. The Archaeological Society of New Mexico No. 37, Albuquerque. Arnold, Dean E.

1985 Ceramic Theory and Cultural Process. Cambridge University Press, Cambridge. Barnett, Franklin

1969 Tonque Pueblo: A Report of Partial Excavation of an Ancient Pueblo IV Indian Ruin in New Mexico. The Albuquerque Archaeological Society, Albuquerque. Baxter, Michael J. 
2003 Exploratory Multivariate Analysis in Archaeology. Edinburgh University Press, Edinburgh.

Bice, Richard A.

1990 The Tunque Legacy: Resources for Study. In Clues to the Past: Papers in Honor of William M. Sundt edited by M. S. Duran and D. T. Kirkpatrick, pp. 29-45. The Archaeological Society of New Mexico No. 16, Albuquerque.

Bishop, Ronald L., Robert L. Rands, and George R. Holley

1982 Ceramic Compositional Analysis in Archaeological Perspective. In Advances in Archaeological Method and Theory, vol. 5, edited by Michael B. Schiffer, pp. 275-330. Academic Press, New York.

Blinman, Eric, Kari L. Schleher, Tom Dickerson, Cynthia Herhahn, and Ibrahim Gundiler

2012 Making a Glaze: Multiple Approaches to Understanding Rio Grande Glaze Paint Technology. In Potters and Communities of Practice: Glaze Paint and Polychrome Pottery in the American Southwest, AD 1250 to 1700. Edited by Linda Cordell and Judith Habicht-Mauche. Anthropological Papers of the University of Arizona, Number 75, pg. 107-116. The University of Arizona Press, Tucson, AZ. Capone, Patricia 2006 Rio Grande Glaze Ware Technology and Production: Historic Expediency. In The Social Life of Pots: Glaze Wares and Cultural Dynamics in the Southwest, $A D$ 1250-1680 edited by J. A. Habicht-Mauche, S. L. Eckert, and D. L. Huntley, pp. 216-231. The University of Arizona Press, Tucson.

Cogswell, James W., David R. Abbott, Elizabeth J. Miksa, Hector Neff, Robert J. Speakman, Michael D. Glascock 
2005 A Provenance Study of Hohokam Schist-tempered Pottery and Raw Materials from the Middle Gila River Valley, Arizona: Techniques and Prospects. In Laser Ablation-ICP-MS in Archaeological Research edited by R. J. Speakman and J. Neff, pp. 105-116. University of New Mexico Press, Albuquerque.

Crane, Leo

1928 Desert Drums. Little, Brown, and Company, Boston.

Creamer, Winifred

2000 Regional Interactions and Regional Systems in the Protohistoric Rio Grande. In The Archaeology of Regional Interaction: Religion, Warfare, and Exchange Across the American Southwest and Beyond, edited by Michelle Hegmon, pp. 99-118. Proceedings of the 1996 Southwest Symposium.

Creamer, Winifred and Jonathan Haas

1998 Less than Meets the Eye: Evidence for Protohistoric Chiefdoms in Northern New Mexico. In Chiefdoms and Chieftaincy in the Americas, edited by E. M. Redmond, 43-67. University of Florida Press, Gainesville.

Crown, Patricia L. 1994 Ceramics and Ideology: Salado Polychrome Pottery. University of New Mexico Press, Albuquerque.

Crown, Patricia L., Janet Orcutt and Timothy Kohler

1996 Pueblo Cultures in Transition: The Northern Rio Grande. In Pueblos Cultures in Transition edited by M. Adler, pp. 188-204. The University of Arizona Press, Tucson. Dillingham, Rick

1992 Acoma \& Laguna Pottery. School of American Research Press, Santa Fe. Disbrow, Alan E. and Walter C. Stoll 1957 Geology of the Cerillos Area, Santa Fe County, New Mexico. New Mexico 
Institute of Mining and Technology Bulletin 48.

Duwe, Samuel, and Hector Neff

2007 Glaze and Slip Pigment Analyses of Pueblo IV Period Ceramics from Eastcentral Arizona using time of flight-laser ablation-inductively coupled plasma-mass spectrometry (TOF-LA-ICP-MS). Journal of Archaeological Science 34:403-414.

Eckert, Suzanne L.

2006 The Production and Distribution of Glaze-Painted Pottery in the Pueblo Southwest: A Synthesis. In The Social Life of Pots: Glaze Wares and Cultural Dynamics in the Southwest, AD 1250-1680 edited by J. A. Habicht-Mauche, S. L.

Eckert, and D. L. Huntley, pp. 34-59. The University of Arizona Press, Tucson. Eckert, Suzanne L.

2008 Pottery and Practice: The Expression of Identity at Pottery Mound and Hummingbird Pueblo. University of New Mexico Press, Albuquerque.

Fenn, Forrest

2004 The Secrets of San Lazaro Pueblo. One Horse Land \& Cattle Co, Santa Fe, NM.

Glowacki, Donna M., Hector Neff, and Michael Glascock

1998 An Initial Assessment of the Production and Movement of 13th Century

Ceramic Vessels in the Mesa Verde Region. Kiva 63(3): 217-240.

Gratuze, Bernard

1999 Obsidian Characterization by Laser Ablation ICP-MS and its Application to Prehistoric Trade in the Mediterranean and the Near East: Sources and Distribution of Obsidian within the Aegean and Anatolia. Journal of Archaeological Science 26: 869-881.

Gratuze, Bernard, Maryse Blet-Lemarquand, and Jean-Noël Barrandon 
2001. Mass Spectrometry with Laser Sampling: A New Tool to Characterize Archaeological Materials. Journal of Radioanalytical and Nuclear Chemistry 247: 645-656.

Habicht-Mauche, Judith A.

1993 The Pottery from Arroyo Hondo Pueblo, New Mexico: Tribalization and Trade in the Northern Rio Grande. Arroyo Hondo Archaeological Series, vol. 8. School of American Research, Santa Fe.

Habicht-Mauche, Judith A.

2002 Torturing Sherds: Ceramic Petrography and the Development of Rio Grande Archaeology. In Traditions, Transitions, and Technologies: Themes in Southwestern Archaeology, edited by S. Schlanger, pp. 49-58. University of Colorado Press, Boulder.

Habicht-Mauche, Judith A., Stephen T. Glenn, Homer Milford, and A. Russell Flegal 2000 Isotopic Tracing of Prehistoric Rio Grande Glaze-Paint Production and Trade. Journal of Archaeological Science 27: 709-713.

Habicht-Mauche, Judith A., Stephen T. Glenn, Mike P. Schmidt, Rob Franks, Homer Milford, and A. Russell Flegal

2002 Stable Lead Isotope Analysis of Rio Grande Glaze Paints and Ores Using ICPMS: A Comparison of Acid Dissolution and Laser Ablation Techniques. Journal of Archaeological Science 29: 1043-1054.

Habicht-Mauche, Judith A., Suzanne L. Eckert, Deborah L. Huntley [editors] 2006 The Social Life of Pots: Glaze Wares and Cultural Dynamics in the Southwest, $A D$ 1250-1680. The University of Arizona Press, Tucson.

Herhahn, Cynthia L. 
2006 Inferring Social Interactions from Pottery Recipes: Rio Grande Glaze Paint Composition and Cultural Transmission. In The Social Life of Pots: Glaze Wares and Cultural Dynamics in the Southwest, AD 1250-1680 edited by J. A. Habicht-Mauche, S. L. Eckert, and D. L. Huntley, pp. 179-196. The University of Arizona Press, Tucson.

Huntley, Deborah L. 2008 Ancestral Zuni Glaze-Decorated Pottery: Viewing Pueblo IV Regional Organization through Ceramic Production and Exchange. Anthropological Papers of the University of Arizona 72. University of Arizona Press, Tucson.

Huntley, Deborah L., Katherine A. Spielmann, Judith A. Habicht-Mauche, Cynthia L. Herhahn, and A. Russell Flegal

2007 Local Recipes or Distant Commodities? Lead Isotope and Chemical Compositional Analysis of Glaze Paints from the Salinas Pueblos, New Mexico. Journal of Archaeological Science 34(7):1135-1147.

Huntley, Deborah L., Thomas Fenn, Judith Habicht-Mauche, and Barbara Mills 2012 Embedded Networks? Pigments and Long-Distance Procurement Strategies in the Late Prehispanic Southwest. In Potters and Communities of Practice Glaze Paint and Polychrome Pottery in the American Southwest, AD 1250 to 1700, edited by L. S. Cordell and J. A. Habicht-Mauche, pp. 8-18. Anthropological Papers of the University of Arizona 75. University of Arizona Press, Tucson. Kelley, Vincent C. and S. A. Northrop 1975 Geology of Sandia Mountains and vicinity, New Mexico: New Mexico Bureau of Mines and Mineral Resources Memoir 29 Kidder, Madeleine A., and Alfred V. Kidder 
1917 Notes on the Pottery of Pecos. American Anthropologist 19(3):333-337.

Kidder, Alfred V., and Anna O. Shepard

1936 The Pottery of Pecos Volume II: The Glaze-Paint, Culinary, and Other Wares.

Yale University Press, New Haven.

Kintigh, Keith W. and Albert J. Ammerman

1982 Heuristic Approaches to Spatial Analysis in Archaeology. American Antiquity

47(1):41-63.

LeFree, Betty

1975 Santa Clara Pottery Today. University of New Mexico Press, Albuquerque.

Lee, W. T.

1907 Water resources of the Rio Grande Valley in New Mexico and their

development: U. S. Geological Survey Water-Supply and Irrigation Paper 188, pp. 7-

56

Mera, H. P.

1933 A Proposed Revision of the Rio Grande Glaze Paint Sequence. Technical Series, Bulletin No. 5, Archaeological Survey/The Laboratory of Anthropology, Santa Fe. Morales, Thomas M.

1997 Glazeware pottery production and distribution in the upper-middle Rio Grande Valley. Unpublished PhD dissertation, Department of Anthropology, University of New Mexico, Albuquerque.

Najohai, Milford and Eliza Phelps

1998 Dialogues with Zuni Potters. Ashiwi Publishing, Zuni.

Neff, Hector 
2003 Analysis of Mesoamerican Plumbate Pottery Surfaces by Laser AblationInductively Coupled Plasma-Mass Spectrometry (LA-ICP-MS). Journal of Archaeological Science 30: 21-35.

Nelson, Nels C.

1916 Chronology of the Tano Ruins, New Mexico. American Anthropologist 18(2):159180.

Nelson, Kit and Judith A. Habicht-Mauche 2006 Lead, Paint, and Pots: Rio Grande Intercommunity Dynamics from a Glaze Ware Perspective. In The Social Life of Pots: Glaze Wares and Cultural Dynamics in the Southwest, AD 1250-1680 edited by J. A. Habicht-Mauche, S. L. Eckert, and D. L. Huntley, pp. 197-215. The University of Arizona Press, Tucson. Parsons, Elsie Clews 1932 Isleta, New Mexico. Forty-seventh Annual Report of the Bureau of American Ethnology, 1929-1930. Smithsonian Institution, Washington, D. C. Ramenofsky, Ann F.

2012 Cieneguilla Glaze-on-yellow: Temporal Measurement and Learning Traditions at San Marcos Pueblo, North-central New Mexico. In Potters and Communities of Practice Glaze Paint and Polychrome Pottery in the American Southwest, AD 1250 to 1700, edited by L. S. Cordell and J. A. Habicht-Mauche, pp. 85-96. Anthropological Papers of the University of Arizona 75. University of Arizona Press, Tucson. Ramenofsky, Ann F., Fraser D. Neiman, and Christopher D. Pierce 2009 Measuring Time, Population, and Residential Mobility from the Surface at San Marcos Pueblo, North Central New Mexico. American Antiquity 7(3): 505-530. 
Ramenofsky, Ann F. and Kari L. Schleher, editors

2017 The archaeology and history of Pueblo San Marcos, New Mexico. The University of New Mexico Press, Albuquerque, NM.

Reed, Lori S.

1990 X-Ray Diffraction Analysis of Glaze-Painted Ceramics from the Northern Rio Grande Region, New Mexico. In Economy and Polity in Late Rio Grande Prehistory, edited by Steadman Upham and Barbara D. Staley, pp. 90-149. University Museum Occasional Papers 16, New Mexico State University, Las Cruces.

Schleher, Kari L.

2010 The Role of Standardization in Specialization of Ceramic Production at San Marcos Pueblo, New Mexico. Unpublished PhD. Dissertation, University of New Mexico, Albuquerque.

Schleher, Kari L., Deborah L. Huntley, and Cynthia L. Herhahn 2012 Glazed Over: Composition of Northern Rio Grande Glaze Ware Paints from San Marcos Pueblo. In Potters and Communities of Practice: Glaze Paint and Polychrome Pottery in the American Southwest, AD 1250 to 1700 edited by L. Cordell and J. Habicht-Mauche, pg. 97-106. Anthropological Papers of the University of Arizona, Number 75, The University of Arizona Press, Tucson.

Schleher, Kari L., Ann F. Ramenofsky, and Judith A. Habicht-Mauche 2002 Local or Non-local Production?: A Comparison of Clay Sources and Sherds from San Marcos Pueblo. Poster presented at the Society for American Archaeology Annual Meeting, Denver.

Scholle, Peter A. 
2003 New Mexico Bureau of Geology and Mineral Resources, Geologic Map of New Mexico, 1:500,000: New Mexico Bureau of Geology and Mineral Resources. Socorro, New Mexico.

Shennan, Stephen

1997 Quantifying Archaeology. Academic Press, New York.

Shepard, Anna O.

1942 Rio Grande Glaze Paint Ware: A Study Illustrating the Place of Ceramic

Technological Analysis in Archaeological Research. Contributions to American Anthropology and History, 7(39): 129-262. Carnegie Institution of Washington, Washington, D.C.

Snead, James E., Winifred Creamer, and Tineke Van Zandt 2004 "Ruins of Our Forefathers": Large Sites and Site Clusters in the Northern Rio Grande. In The Protohistoric Pueblo World A.D. 1275-1600. edited by C. E. Adams and A. I. Duff, pp. 26-34. The University of Arizona Press, Tucson. Speakman, Robert J., Neff, Hector 2005 The Application of Laser Ablation-ICP-MS to the Study of Archaeological Materials - An Introduction. In Laser Ablation-ICP-MS in Archaeological Research edited by R. J. Speakman, and H. Neff, pp. 1-16. University of New Mexico Press, Albuquerque, New Mexico, pp. 1-16.

Spielmann, Katherine A.

1994 Clustered Confederacies: Sociopolitical Organization in the Protohistoric Rio Grande. In The Ancient Southwestern Community: Models and Methods for the Study of Prehistoric Social Organization edited by W. H. Wills and R. D. Leonard, pp. 45-54. University of New Mexico Press, Albuquerque. 
Spielmann, Katherine A.

1998 Ritual Influences on the Development of Rio Grande Glaze A Ceramics. In Migration and Reorganization: The Pueblo IV Period in the American Southwest edited by K. A. Spielmann, pp. 253-261. Anthropological Research Papers No. 51. Arizona State University, Tempe.

Stearns, Charles E.

1943 The Galisteo Formation of North-Central New Mexico. The Journal of Geology 51(5): 301-319.

Stearns, Charles E.

1953 Tertiary Geology of the Galisteo-Tonque Area, New Mexico. Bulletin of the Geological Society of America 64: 459-508.

Warren, A. Helene

1969 Tonque: One Pueblo's Glaze Pottery Industry Dominated Middle Rio Grande Commerce. El Palacio 76(2):36-42.

Warren, A. Helene

1979 The Glaze Paint Wares of the Upper Middle Rio Grande. In Archaeological Investigations in Cochiti Resevoir, New Mexico, Vol. 4: Adaptive Changes in the Northern Rio Grande Valley, edited by J. V. Biella and R. C. Chapman, pp. 187-216. Office of Contract Archaeology, Department of Anthropology, University of New Mexico, Albuquerque.

Warren, A. Helene

1981 A Petrographic Study of the Pottery. In Contributions to Grant Quivira Archaeology edited by A. C. Hayes, pp. 67-73. Publications in Archaeology No. 17. National Park Service, U. S. Department of the Interior, Washington D. C. 
Whiteley, Peter

2004 Social Formations in the Pueblo IV Southwest: An Ethnological View. In The Protohistoric Pueblo World A.D. 1275-1600. edited by C. E. Adams and A. I. Duff, pp. 144-145. The University of Arizona Press, Tucson.

Wilcox, David R.

1991 Changing Contexts of Pueblo Adaptation, A.D. 1250-1600. In Farmers, Hunters, and Colonists: Prehistoric and Historic Plains-Pueblo Exchange edited by K. A. Spielmann, pp. 128-154. University of Arizona Press, Tucson. 